\title{
Derivatives as the Price Fluctuation Risk Management for Vietnamese Coffee Exporters
}

\author{
Dinh Xuan Cuong ${ }^{1} \&$ Nguyen Quoc Toan ${ }^{2}$ \\ ${ }^{1}$ Vietnam National University, Hanoi, Vietnam \\ ${ }^{2}$ Central Economic Commission, PCV, Hanoi, Vietnam \\ Correspondence: Dinh Xuan Cuong Ph.D., Vietnam National University, 144 Xuan Thuy Road, Cau Giay District, \\ Hanoi, Vietnam. \\ Received: March 13, 2016 \\ Accepted: April 4, 2016 \\ Online Published: April 15, 2016 \\ doi:10.5430/rwe.v7n1p59 \\ URL: http://dx.doi.org/10.5430/rwe.v7n1p59
}

This research is funded by Vietnam National University, Hanoi (VNU) under project number QG.16.54.

\begin{abstract}
Our research on derivative tools to hedge price fluctuation risk of coffee exporting corporations in Vietnam. Derivatives in Vietnam are in their developing process, the development of commodity exchanges in Vietnam is still disadvantageous. The coffee export sector has reached some significant achievements and is expected to develop. The establishment of tools to hedge price fluctuation of exporters in Vietnam is limitable.
\end{abstract}

Keywords: commodity derivative, price risk, Vietnamese coffee

\section{Introduction}

Vietnam is among countries having the biggest advantage in developing agriculture and Vietnam produce plays an important role in produce commodity exchange of the world. According to statistics from the ministry of agriculture and rural development, in 2014 Vietnam export output was 1908 thousand tons in crop year 2013-2014, equal 3327 million USD. The coffee industry has experienced a considerable development from a moderate producer to second biggest coffee producing country. According to International Coffee Organization (ICO), in year 2014, Vietnam continues to hold the position 'runner-up' in coffee exports, behind Brazil but far ahead of other competitors.

Despite a big advantage of coffee export, commercial contracts are conducted mainly in the traditional way, which means brokers are bridge of sellers and buyers. Therefore, farmers and coffee corporations still face many risks in commodity markets (Nguyen 2014). Derivative exchange can ensure fluctuation in commodity market. According to International Swaps and Derivatives Association 2003, 92\% in 500 world biggest corporations manage risk by using derivative commodity. Derivatives are very useful for players in commodity - producing developing countries. Management of the risks associated with price variation can provide many advantages to participants in the coffee sector in exporting countries. Furthermore, the use of derivative tools allows exporters to adopt a flexible strategy for supplying the international market. At the same time, it mean exporters will protect the value of their coffee stocks to regulate market supply and thereby avoid triggering price falls through large releases to the market (ICO, 2003). Besides, the effectiveness of financial market lowers fee of capital, allowing corporations access and take advantage of their loan (Carmichael and Pomerleano, 2002; Domowitz and Steil, 2002).

Many countries have used derivatives successfully to manage the fluctuation price risk of agricultural exports including coffee. The most popular method is building trading commodity futures contract market where the manufacturers and the agricultural export transactions take part in to share risk on commodity prices for partners on the domestic market and the international market. These contracts are transacted through large commodity trading centers such as in New York Board of Trade (NYBOT), London International Financial Futures and Options Exchange (LIFFE), Marché international des Cafés Robusta da Paris (MATIF), Bolsa de Marcadorias \& Futuros BM\&F (the Brazilian Mercantile \& Futures Exchange), Tokyo Grain Exchange (TGE), Singapore Commodity Exchange. As a result, derivative development is very necessary in Vietnam when transaction products for commodities, including coffee will grow strongly in the present and future. 
In Vietnam, derivative exchanged started in 2005- 2006 through products of future contract conducted by some commercial banks. In addition, two future commodity exchanges Vietnam commodity exchange and Buon Ma Thuot coffee and commodity exchange center went on operation. In spite of the appearance of two exchanges, this type of exchange has not attracted many customers (Ho and Vo, 2015). The issue is why the performance of two commodity exchanges is not effective and how to develop derivatives in Vietnam.

Since above reasons, the purpose of our paper is to study and analyze the impact of using derivatives in price fluctuation risk management for Vietnamese coffee exporters.

\section{Literature Review}

There are many researches related to how to use derivatives as the risk management such as "The effects of derivatives on firm financial risk: an analysis of UK non-financial firms" (Finavker, 2014), "Companies and derivatives as a tool to hedge their risk" (Radomir Cisar, in 2010), "Hedging to safety: A political economy of derivatives, risk and agriculture in the developing world" (Breger Bush and Sasha Coler, 2009), "Price risk management in the copper market using commodity derivatives and options strategies" (Bold Sandagdorj, 2005).

In Vietnam, there are also researches related to that issue: "Development of derivatives on stock market Vietnam" (Bui Thuy Nam, 2010), "The uses of derivatives as price risk management for Vietnamese agricultural exporters" (Le Hoang Long, 2008), "Development the futures market to hedge price fluctuation risk for futures markets to hedge price fluctuations for Vietnamese coffee exporters" (Nguyen Thi Hoi, 2012). However, those studies are not appropriate with the actual conditions of Vietnam because the derivatives market has not developed in Vietnam. We aim to update more information about the legal development of the derivatives market in Vietnam and show currently actual conditions or Vietnam when the Government has set the legal framework for trading derivative securities in 2015.

\section{Commodity derivative in hedging risk management}

According to previous analysis which concluded that the beneficiary from using commodity derivative including: export enterprise, growers and government (Akiyama and Christian, 2001; Patrick de Fontenay and Suiwah Leung, 2002).

Derivatives are very useful for players in commodity producing developing countries. Management of the risks associated with price variation can provide many advantages to participants in the coffee sector in exporting countries. By using of tool of commodity derivative will assist local buyers and export to protect profits margins from price fluctuation which, in turn, will allow them to pay producers relatively high prices. Where the possibility to utilize these tools does not exist, buyer and exports will be obliged to deduct large margins from price paid to producers to make provision for downturns in international prices. It is obvious that exporters will protect the value of their coffee stock to regulate market supply and thereby avoid issues of price falls through large releases to the market (ICO, 2003). There is an advantage of commodity derivative for exporting firms.

Moreover, one obvious beneficiary of commodity derivatives world be growers. In Costa Rica, by researching coffee industry from 1983 to 1998, it was found that, under a program of participatory options hedge, the average revenue received by the coffee grower was less than the prevailing market prices in 38 out of 110 months in the program period, but above the market in 72 months. Furthermore, in some months, the revenue of 13 producers would have been significantly higher than market prices (Akiyama and Christian 2001). The benefit of small growers is apparent.

Derivatives play an important role in determining price of one product, eliminating risks in price change and increase the effectiveness of financial market through multi-lateral exchange market and fine regulations in publishing price. Besides, when financial market performs better the fee of capital will decrease, allowing corporations access and invest their capital in the most effective way (Carmichael and Pomerleano, 2002; Domowitz and Steil, 2002).

These are the advantages of derivatives for corporations and producers. For some developing countries and Vietnam in particular, the development of derivatives is crucial. The previous are some proofs given by writer why derivatives are important.

Moreover, effects of world crisis in economic and finance, Geek government debt crisis, political instability in Middle East, Africa are significant in some economies. WB, ADB and other organizations have forecasted that the global climate change decrease coffee production seriously. The mentioned factors have a big influence on the fluctuation of coffee price. Therefore, risk management is a must.

Another reason is the development trend of commodity exchange or in other word the bloom of derivative tools. There are around 30 commodity exchanges in the world business, 13 in America, 14 in Asia and 5 in Europe selling 
farm produce material. In terms of operation scope, the exchanges not only run their operation in the boundary of one country but also expand to global market such as NYBOT, LIFFE, TOCOM, ICE.

Under this trend, Vietnam is undergoing a sound transformation and a deep integration. Custom product section is also developing. However, Vietnam is lacking powerful regulations in commodity markets to support economic activities. After establishment, commodity markets which are now unable to connect to investors have functioned well and mainly conduct direct delivery.

\section{Process development of derivatives in Vietnam}

Derivative products emerged in Vietnam 16 years ago in 1999. Under Decision 65/1999 on $25^{\text {st }}$ Feb 1999, forward contract was seen as the first derivative tool in Vietnam. In regarding with option contract there are some option products such as foreign currency, gold, interest. Option interest is applied to middle-dated and long term in USD and Euro for Vietnam-based corporations, commercial banks and foreign banks in Vietnam are approved to function by state bank. Option foreign currency enable individuals and corporations place buying and selling orders in USD and EURO, some commercial such as BIDV, Eximbank, ACB, Techcombank, Agribank offer this service. On $10^{\text {st }}$ Dec, ACB was the first bank offering option gold, followed by the application of Sacombank, Agribankduring the continuous increase of domestic and world gold price. Under Decision 430 on $24^{\text {st }}$ Dec 1997, which later was decision $893 / 2001$ on $17^{\text {st }}$ Jul 2001 exchange contracts was put into effect. As we can see, option products are sufficient, their performance; however, it is neutral effective enough and authorities should pay more attention on them.

Above mentioned information is about derivative products including gold, interest and foreign currency. Besides, in Vietnam there are some commodity derivatives on commodity exchanges Cashew commodity exchange and Can Gio ATC exchange were established. Nonetheless, these exchanges existed many drawbacks and closed down in a short time after their establishment. In last months of 2006, the government issued decision 158/2006 about setting up a central commodity market hosted by the ministry of trade and industry in cooperation with the Ministry of investment, the ministry of Finance and the Ministry of Agriculture and rural development. However, authority body of derivative market such as the committee of state stock has not joined in so that the operation of commodity derivatives is not considerable. Therefore, Buon Ma Thuot coffee and commodity exchange center and Ho Chi Minh commodity exchange closed down after a short time doing business. The following is establishing a period of some commodity exchanges.

Table 1. Process development of commodity exchange in Vietnam

\begin{tabular}{lcc}
\hline \multicolumn{1}{c}{ Exchange } & Setting up year & Performance \\
\hline Cashew commodity exchange & $\mathrm{T} 3 / 2002$ & Stop \\
\hline CangioATC & $\mathrm{T} 5 / 2002$ & Stop \\
\hline Sacombank steel exchange & 2009 & \\
\hline Buonmathuot Coffee And Commodity Exchange (BCEC) & 2008 & Stop \\
\hline Sacom sugar trading exchange - STE & 2010 & Stop \\
\hline Viet Nam Commodity Exchange (VNX) & $\mathrm{T} 9 / 2010$ & Stop \\
\hline Info Comex & 2013 & \\
\hline
\end{tabular}

Source: Authors's summary

A conclusion drawn from the performance of commodity exchanges in Vietnam is the system of commodity and derivative exchange-related legislative document is not clear and specific enough for partners in market. Most of commodity exchange now is under standard, loose in legislative regulations and operational rules, leading to conflicts and instability. Governments support derivatives in other countries; meanwhile, Vietnam government has not issued legislative regulations to encourage the development of exchanges and protect investors with regulation relating to capital- saving, settling support and other risk management tools (Nguyen Phuoc Kinh Kha 2014)

In order to encompass legislative regulation for the operation of derivatives on $11^{\text {st }}$ March 2014, the government approved the project called project of establishment and development of Vietnam derivatives. Under the guidance of this project, stock derivative need to follow a schedule from the simple to the complicated to ensure management 
capacity and risk management in market. Moreover, on $15^{\text {st }}$ May 2015, the government issued decision 42/2015 about derivative stock and stock derivatives.

\section{Summary of Vietnam Coffee Export}

\section{Overview of coffee export sector of Vietnam}

Coffee trees were brought into Vietnam by French in 1850s. However, producing activities were not effective and organized. Until 1975 when people started immigrating from the delta and coastal areas to the highland where there is a favorable conditions to grow coffee, producing activities were expanded but still small. When renewal process was implemented in 1986, coffee trees were grown and produced with large scale. Below is some features of coffee export field in Vietnam including export companies, outputs and Vietnam Coffee's export values, Vietnamese Coffee's market share.

Coffee planning's square

Table 2. Coffee square regards to provinces in Vietnam

(Unit: hectare)

\begin{tabular}{|c|c|c|c|c|}
\hline & 2012 & 2013 & 2014 & Target in 2020 \\
\hline Dak Lak & 202,022 & 207,152 & 210,000 & 170,000 \\
\hline Lam Dong & 145,735 & 151,565 & 153,432 & 135,000 \\
\hline Dak Nong & 116,350 & 122,278 & 122,278 & 69,000 \\
\hline Gia Lai & 77,627 & 77,627 & 78,030 & 73,000 \\
\hline Dong Nai & 20,000 & 20,000 & 20,800 & 13,000 \\
\hline Binh Phuoc & 14,938 & 14,938 & 15,646 & 8,000 \\
\hline Kontum & 12,158 & 12,158 & 13,381 & 12,500 \\
\hline Quang Tri & 5,050 & 7,071 & 15,000 & 5,000 \\
\hline Son La & 6,371 & 9,000 & 10,650 & 5,000 \\
\hline BaRiaVung Tau & 7,071 & 7,071 & 5,050 & 5,000 \\
\hline Dien Bien & 3,385 & 3,385 & 3,385 & 4,500 \\
\hline Other & 5,700 & 5,700 & 5,700 & - \\
\hline Total & 616,407 & 633,925 & 653,352 & 500,000 \\
\hline
\end{tabular}

Source: Ministry of Agriculture \& Rural Development

DakLak, Lam Dong, DakNong, Gia Lai have a large coffee square in whole country. However, Coffee squares being over 20 years old are more than 100,000 ha which is expected to be up to 150,000 ha in next 5 years. The old coffee trees which are unlikely productive under 15 tons per ha need replanting in the coming time to maintain the coffee outputs. Replanting coffee trees are facing many difficulties as the cost is relatively high and trees are easy to get diseases. In addition, the domestic coffee price is quite high that prevents farmers not eliminating the old trees and growing the new one. The profit can be stabilized by alternating others plants during the young trees are growing. Macadamia tree and avocado tree were alternated on coffee land 4 years ago when replacing the unqualified coffee trees was suitable solution. Because macadamia and avocado trees will fruit during 4 years and farmers will have an aid income while waiting for the growth of young coffee trees.

Ministry of Agriculture \& Rural Development approved Vietnamese Coffee developing plan until 2020 and vision to 2030 in 21 August 2014. According to this approval, in 2020, the total coffee square will reach 500,000ha, coffee bean output will be 1,112,910 tons, manufacturing productivity will be expanded to 125,000 tons in which instant coffee and 3 in 1 coffee will make up 50,000 tons, export turnovers will increase from 2.1 to 2.2 USD billions. Orientation to 2030: total growing coffee of country reaches 479,000 ha, coffee bean output gets 1,122,675 tons, manufacturing productivity continues being expanded to 135,000 tons in which instant coffee and 3 in 1 coffee is about 60,000 tons and export turnover is over 2,2 USD billions. It can be seen that the Government's orientation for the coffee section in the future is to reduce growing square and boost the output per hectare.

\section{Coffee export companies}

Exporting coffee activities still limited only for government-owned corporations until 1999. After this stage, private companies were allowed to engage in exporting coffee market. According to the statistics of General Custom at the 
end of 2014, there are more than 140 companies taking part in exporting coffee with four leading companies: Vietnamese Coffee Company, 2/9 Coffee, Intimex export and import company and Thai Hoa Coporation. However, in the total of 30 export companies have large export revenue, there are 14 firms having foreign investment.

\section{Exporting coffee product structure}

There are two main kinds of coffee, which are Robusta and Arabia coffee in Vietnam. Robusta coffee has a large output in the total of other coffees. According to statistic of Ministry of Agriculture \& Rural Development, Robusta coffee output accounts for 95-96\% of the total of country. While Robusta growing Square makes up 93\% compared to the whole country, Robusta coffee is grown mainly in Highland Central and Arabica coffee is planted in Son La, Dien Bien, Tuyen Quang.

(Unit: thousand 60kg bags)

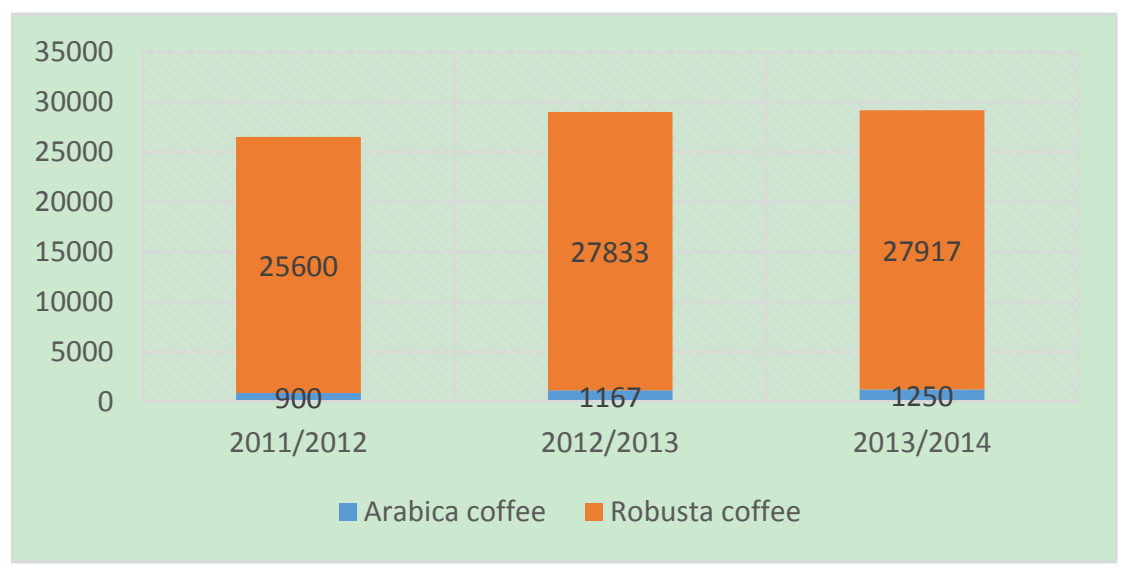

Chart 1. Domestic coffee output in 2011 - 2014

Source: Ministry of Agriculture \& Rural Development

According to statistic of Ministry of Agriculture \& Rural Development, it shows that Robusta and Arabia outputs have increased for three crops. In crop year 2013/2014, the total Robusta coffee outputs reached 27970 thousand $60 \mathrm{~kg}$ bags, Arabia coffee was 1250 thousand $60 \mathrm{~kg}$ bags. This is a statistic about Coffee production in Vietnam regarding to two groups: Robusta and Arabia. The Author will introduce about exporting products of Vietnamese coffee in the following part.

According to statistic of Ministry of Agriculture \& Rural Development, exporting products of Vietnamese coffee is divided into three main groups: coffee bean, roasted coffee and instant coffee. Coffee beans account for a large share in the structure of exports (about 98\% total of exported coffee). By the 2014/2015 crop year, the total amount of exported coffee production reached 26790 thousand bags, roasted coffee and whole bean coffee reached 130 thousand bags and instant coffee was 250000 bags. This data shows that processing content of exported coffee is still low, which will affect to export values of this product. In order to see clearly this impact, a stark example of exported coffee in the United States will be described in detail in the below table.

Table 3. Kinds of exported coffee products of Vietnam to the US in $2011-2013$

\begin{tabular}{lcccc}
\hline & \multicolumn{2}{c}{$\begin{array}{c}\text { Crop year 2011/2012 } \\
\text { (Oct/2011 to Sep/2012) }\end{array}$} & \multicolumn{2}{c}{$\begin{array}{c}\text { Crop year 2012/2013 } \\
\text { (Oct/2012 to Sep/2013) }\end{array}$} \\
\cline { 2 - 5 } & $\begin{array}{c}\text { Value (thousand } \\
\text { USD) }\end{array}$ & $(\%)$ & $\begin{array}{c}\text { Value (thousand } \\
\text { USD) }\end{array}$ & $(\%)$ \\
\hline $\begin{array}{l}\text { Coffee, not roasted, not decaffeinated (HS code } \\
\text { 090111) }\end{array}$ & 570,151 & $91.83 \%$ & 457,973 & $88.94 \%$ \\
\hline $\begin{array}{l}\text { Coffee, not roasted, decaffeinated (HS code } \\
\text { 090112) }\end{array}$ & 33,595 & $5.41 \%$ & 39,141 & $7.60 \%$ \\
\hline
\end{tabular}




\begin{tabular}{|c|c|c|c|c|}
\hline $\begin{array}{l}\text { Coffee, roasted, not decaffeinated (HS code } \\
090121 \text { ) }\end{array}$ & 4,703 & $0.76 \%$ & 4,841 & $0.94 \%$ \\
\hline Coffee, roasted, decaffeinated(HS code 090122 ) & 5,259 & $0.85 \%$ & 1,578 & $0.31 \%$ \\
\hline $\begin{array}{l}\text { Coffee Husks And Skins And Substitutes } \\
\text { Containing Coffee In Any Proportion (HS code } \\
\text { 090190) }\end{array}$ & 74 & $0.01 \%$ & 5 & $0.00 \%$ \\
\hline $\begin{array}{l}\text { Extracts, essences and concentrates (HS code } \\
\text { 210111) }\end{array}$ & 2,943 & $0.47 \%$ & 6,389 & $1.24 \%$ \\
\hline $\begin{array}{l}\text { Preparations with a basis of extracts, essences or } \\
\text { concentrates or with a basis of coffee (HS code } \\
210112 \text { ) }\end{array}$ & 4,162 & $0.67 \%$ & 5,025 & $0.98 \%$ \\
\hline Total & 620,887 & $100.00 \%$ & $\mathbf{5 1 4 , 9 5 2}$ & $100.00 \%$ \\
\hline
\end{tabular}

Source: Global Trade Atlas, United States Department of Commerce

According to this table, with a large market and high consumption like American, Vietnamese exported coffee products are mainly not roasted and not decaffeinated coffee. These products account for nearly $90 \%$ of export revenue to this market. According to the data of American Trade Ministry, exporting crude coffee (not roasted and not decaffeinated coffee) in crop year 2011/2012 reached 570.151millions USD, making up for 91.93\% total of different exported coffee values to the American market. In crop year 2012/2013, this value reduced by 457.973 million USD, approximately $88.94 \%$.

Volume and value of coffee export of Vietnam

Volume and value of coffee export of Vietnam in crop year 1990 - 2014 by ICOis shown in below chart.

(Unit: tons, \%)

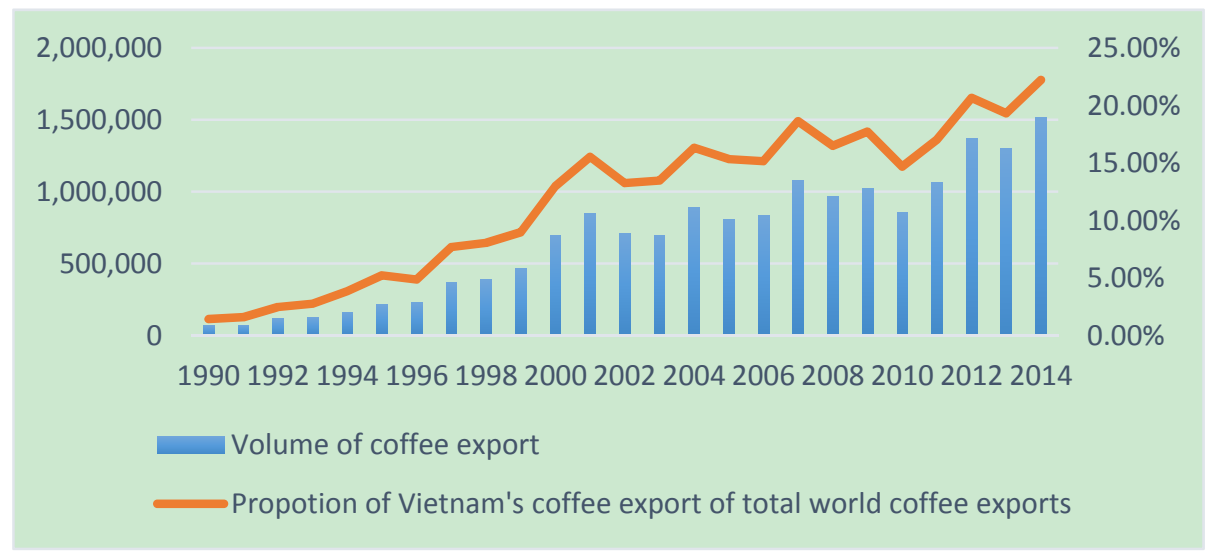

Chart 2. Total volume of coffee export of Vietnam from 1990 to 2014

Source: International Coffee Organization

According to ICO's data, Vietnamese exported coffee output in 1990-2014 increased annually. In 1990, Vietnamese exported coffee volume was at 68,714 tons, accounting for $1.42 \%$ total world coffee export. In 2014, the total of Vietnam's coffee export was ranked in the second position in the world (after Brazil) and top of Robusta coffee export, with a volume of export was 25,298 thousand $60 \mathrm{~kg}$ bags $(1,517,895$ tons) making up for $22.21 \%$ total world coffee exports. The growth of volume of Vietnam's coffee export shows Vietnam's position in the world market. 


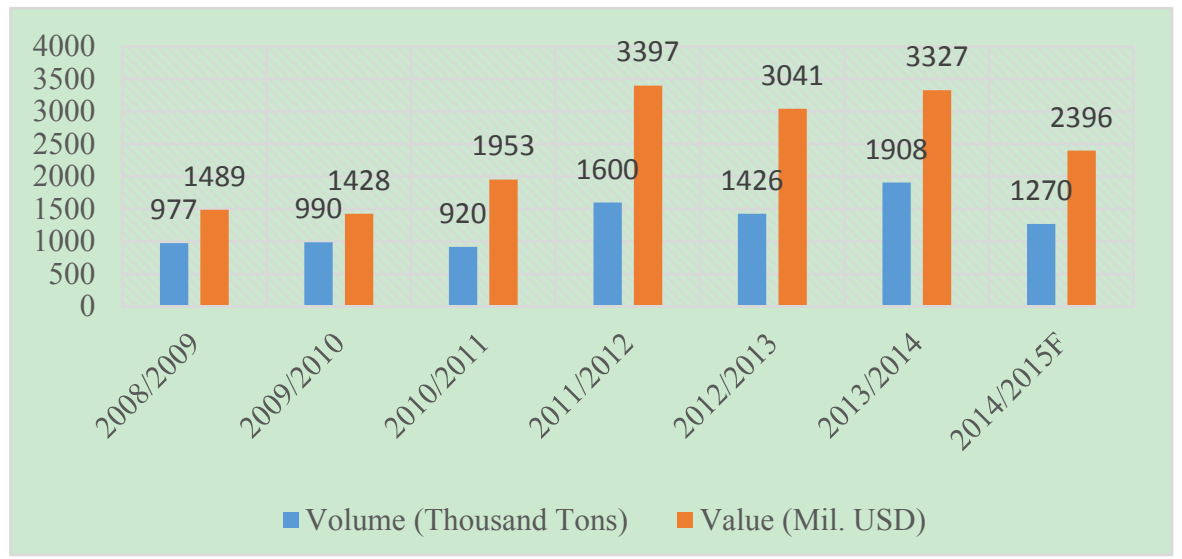

Chart 3. Volume and value of coffee exports of Vietnam from 2009 - 2014

Source: Ministry of Agriculture \& Rural Development

According to the data of Ministry of Agriculture and Rural Development, value and volume of Vietnamese export coffee in 2009-2015 shows that in the period of 2011-2014 Vietnamese export coffee increased strongly both quality and production. Its growth is due to expanding coffee land policy and positive impact of world coffee's price which raised dramatically in crop year 2010-2011 and then decreased in crop year 2012-2013, recovered in crop year 2013-2014. In crop year 2014-2015, Vietnamese coffee's value and output decreased strongly because of world coffee's negative influence. In addition, the impact of the weather like long-lasting drought and the deforestation of coffee to grow peppers in the largest growing coffee area -Highland Center, the competition of growing coffee countries like Indonesia and China are the reasons affecting negatively to Vietnamese export coffee's output. Regarding to report of Ministry of Agriculture and Rural Development, exporting coffee in the nine first months in 2015 was estimated to reach 961 thousand tons with a total value of 1.96 billion USD, declining $31.2 \%$ of weight and $32.2 \%$ of value year on year. The average coffee export's price in eight first months reached 2,054 USD/ton decreasing $0.23 \%$ compared to the same period in 2014 .

World coffee market and Vietnam's coffee share market

In the world import market, EU, USA, Japan, Russia, and Canada are the five areas that have the biggest volume of imported coffee in the world. According to the author's calculation from ICO's database in 2011-2014, total volume of coffee imports of these countries makes up from $78.03 \%-79.83 \%$ percentage of total world coffee imports. In 2011, coffee volume of five largest markets accounted for 79.83\% of total world coffee import and 78.84\% in 2014 .

(Unit: thousand 60kg bags)

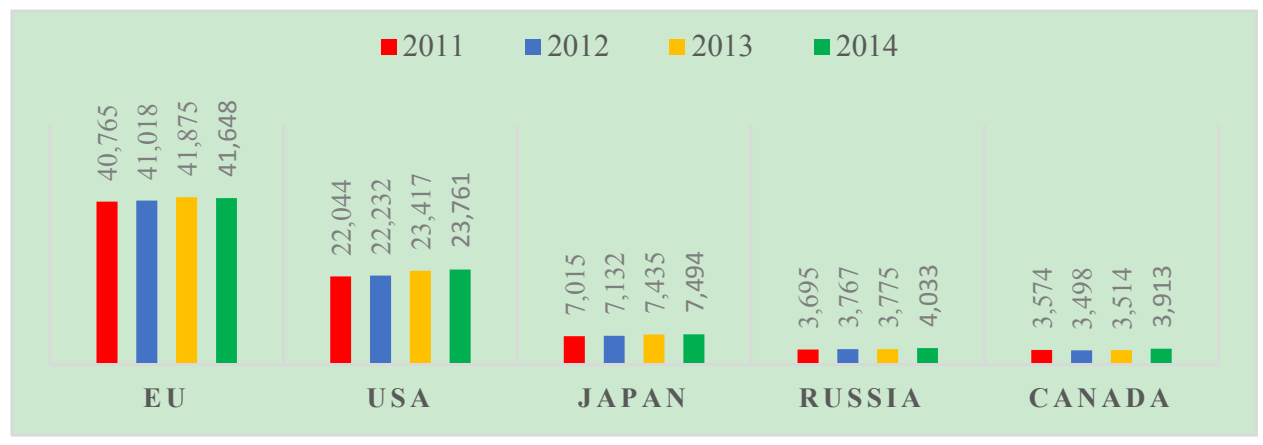

Chart 4. World coffee consumption (2011 - 2004)

Source: International Coffee Organization

Among five leading coffee import market, the volume of imported coffee in EU and USA has the most significant ratio. In 2014, the total volume of imported coffee in EU reached 41,648 thousand $60 \mathrm{~kg}$ bags, approximately 
2,445,900 thousand tons. In American market, the amount of imported coffee increases gradually every year, with 23,761 thousand $60 \mathrm{~kg}$ bags of import volume in 2014 approximately 1,322,000 thousand tons. The following of the world leading coffee consumption are Japan, Russia and Canada, whose volume of imported coffee in 2014 were 7,494 and 4,033 and 3,913 thousand 60kg bags. Countries can expand coffee consuming market those countries that have large purchasing powers and world leading of imported coffee.

There is a coffee consuming market in the world above, Vietnamese coffee exporting market is described in chart below:

(Unit: ton)

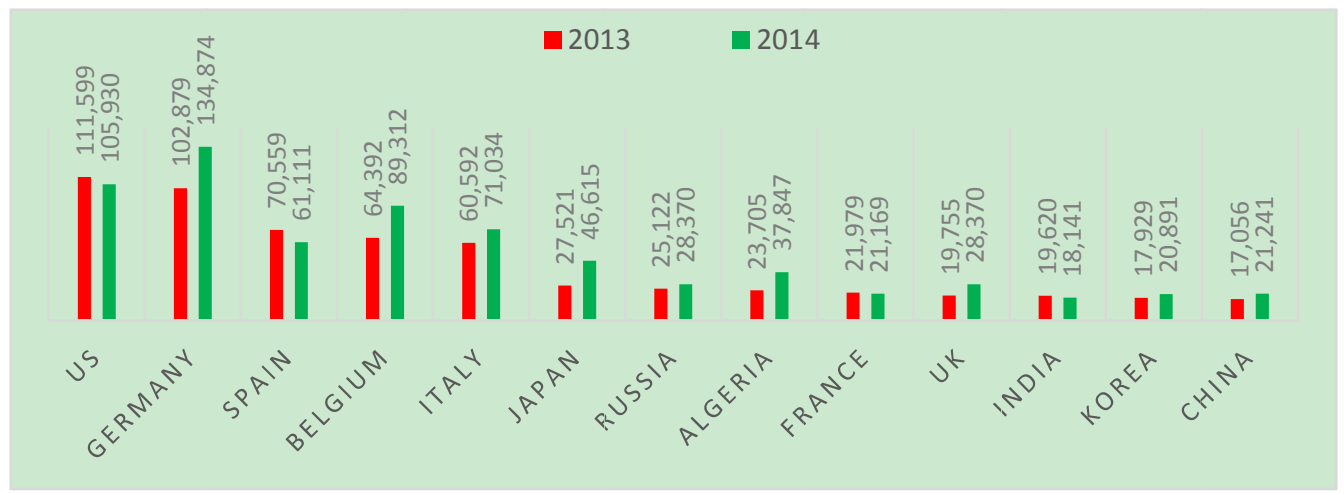

Chart 5. Export market of Vietnam coffee in $2013-2014$

Source: General Department of Vietnam Customs

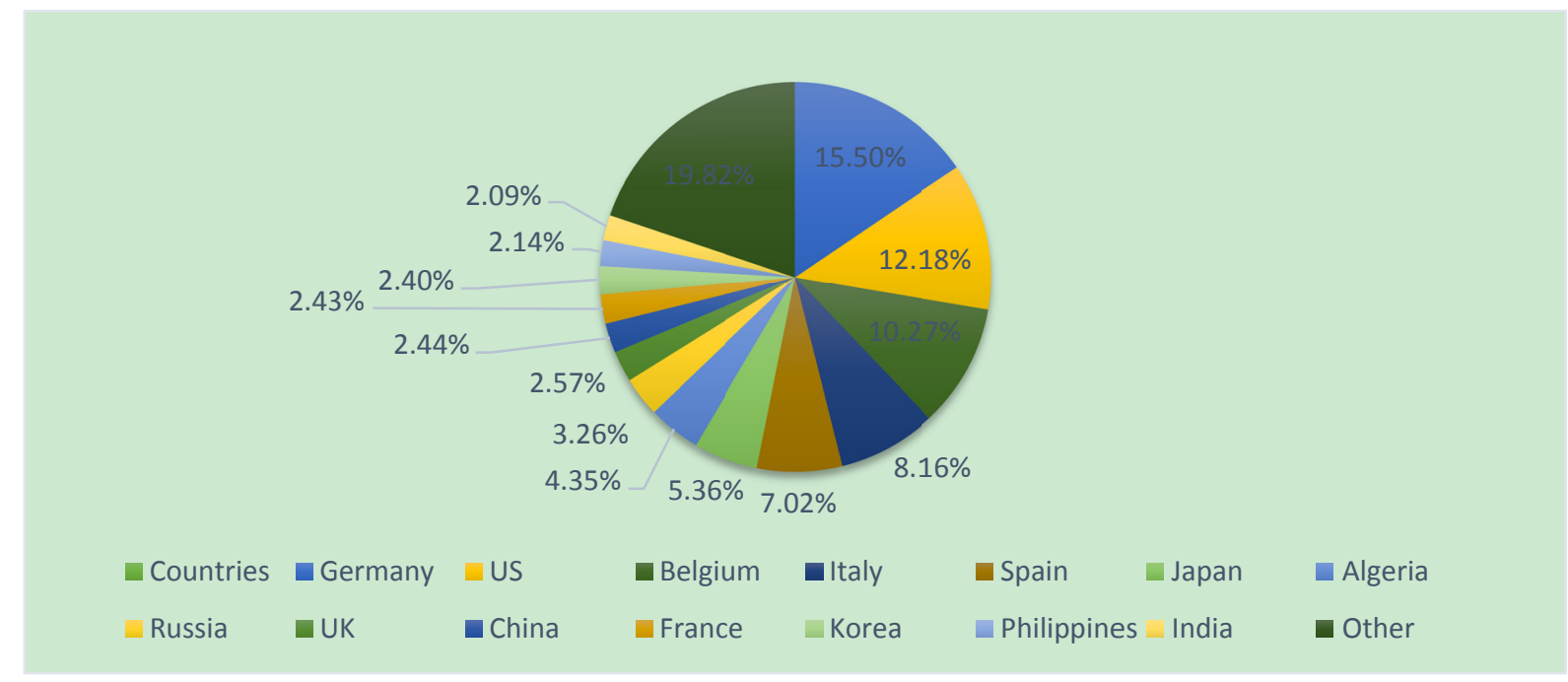

Chart 6. Market share of Vietnam coffee in 2014

Source: General Department of Vietnam Customs

According to data released by General Department of Vietnam Customs, the leading export markets of Vietnam are the US, Germany, Spain, Belgium, Italy, Japan, Russia, Algeria, France and UK. In 2013, the export turnover of Vietnam coffee to the US reached its peak at 111, 599 tons; in 2014 the number was 105,930 tons, coming in the second position among export partners. In 2013, Germany exported 102,879 tons of coffee from Vietnam after that 2014 witnessed the highest number of 134,874 tons, followed by some other European and Asian countries. As can be seen in the chart of Vietnam coffee- imported countries, South America and European are top export markets of Vietnam coffee. 


\section{Fluctuation of coffee price}

Coffee price's fluctuation of international coffee organization in 1990-2015 shows that coffee price fluctuates in different period. The strongest fluctuation in coffee price was in 1994-1998 and 2008-2014. In 2000-2004, coffee price declined strongly, kinds of coffee traded in the market stood at the lowest level in 15 years. Robusta coffee price reached its peak within 15 years in 1994, the average price was 4,030 USD/ton. In six recent years, after the coffee price rocketed in 2010, growing coffee square increased nationwide. Oversupply and other factors were responsible for a deep decrease of coffee price in 2013 witnessing a recovery in 2014. From the end of 2014 to now, coffee price continues declining strongly. The three Arabica groups all saw decreases, with Colombia Milds, Other Milds and Brazilian Naturals down 4.4\%, 3.4\% and 4.6\% respectively. The most significant drop was recorded in Robusta coffee, down $4.9 \%$ to 87.56 cents, their lowest level in 18 months. This decrease in Robusta prices has led to anecdotal reports of stocks accumulating in Vietnam, with sellers reluctant to trade at such low domestic prices. Chart of price fluctuation of Robusta coffee and Arabica coffee, which is built in NYBOT and LIFFE exchange is shown in below chart.

(Unit: Dollars per Kg)

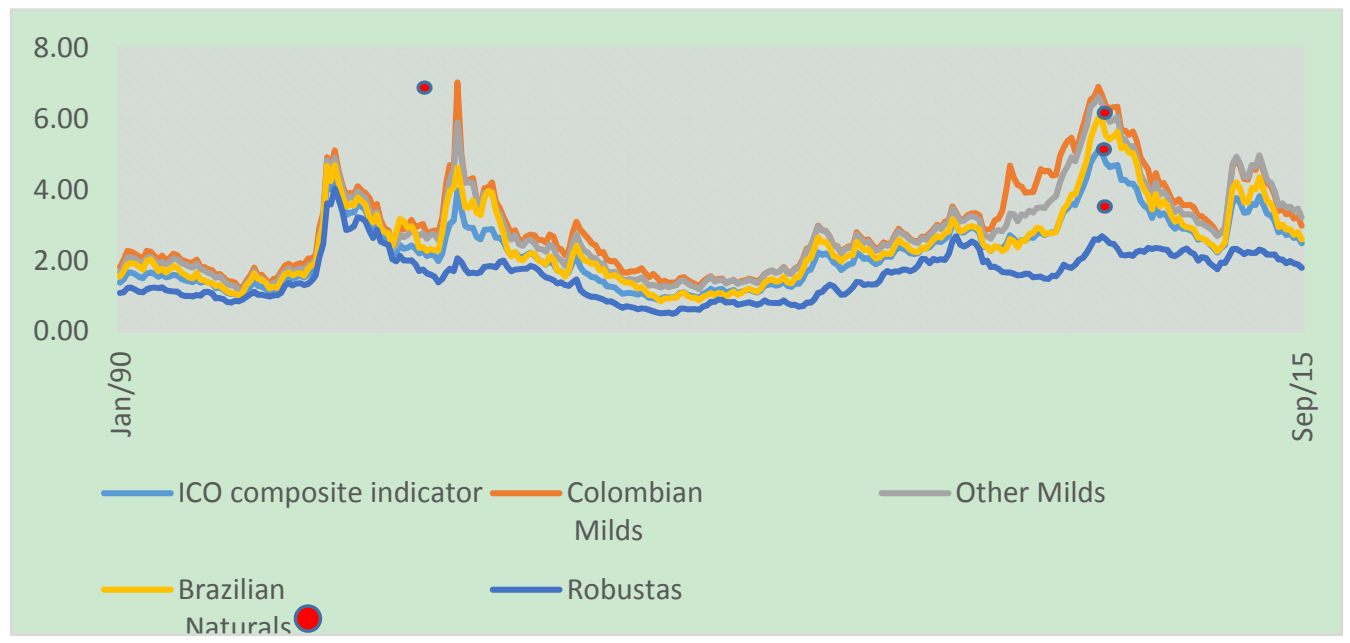

Chart 7. ICO composite and group indicator prices (1990 - 2015)

Source: International Coffee Organization

\section{(Unit: USD/ton)}

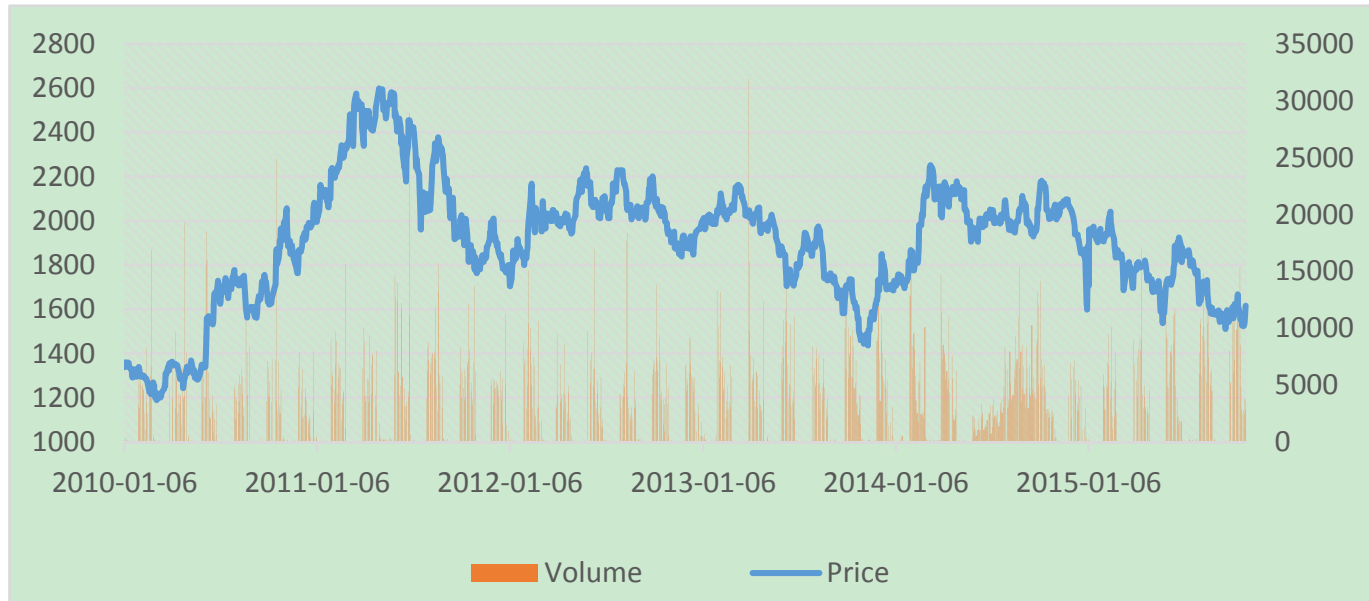

Chart 8. Historical LIFFE futures prices: Robusta coffee futures (2010 - 2015)

Source: Historical LIFFE Futures Prices 
(Unit: Cent/lb)

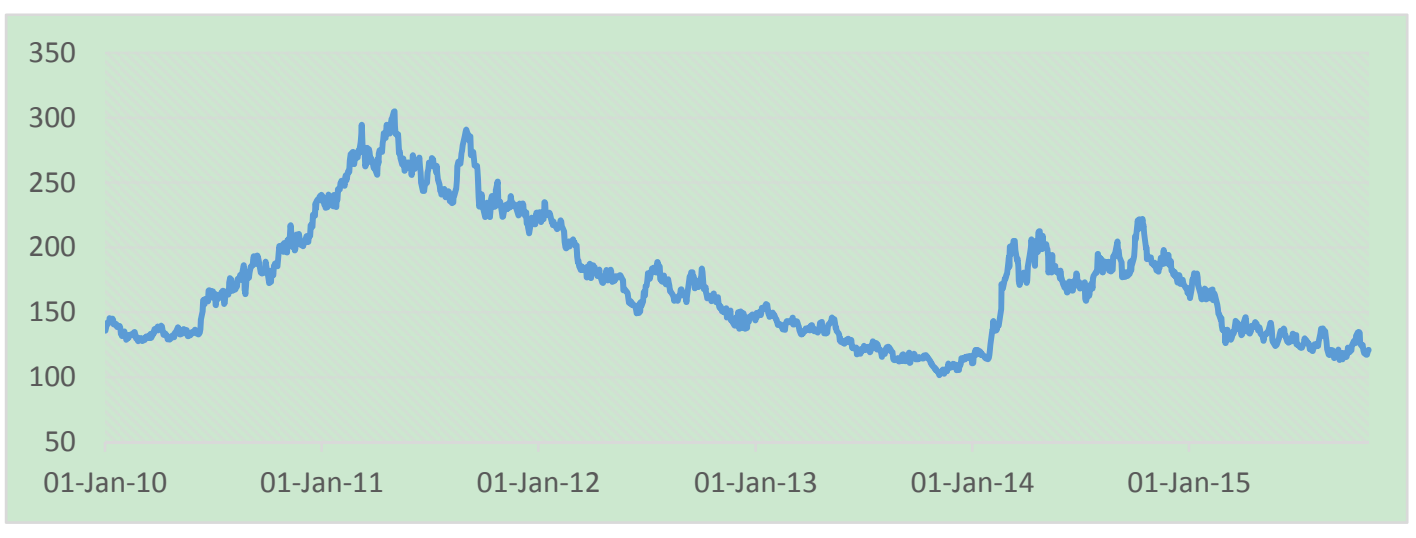

Chart 9. Historical NYBOT futures prices: Arabica coffee futures $(2010-2015)$

Source: Historical ICE Futures Prices

As can be seen in the chart of the fluctuation of directly-delivered coffee in 2 exchanges NYBOT and LIFFE, in the recovery period in2014 the price of Robusta coffee in LIFFE and Arabica coffee in NYBOT witnessed a downward trend. The price of directly- delivered Arabica on ICE in 30 October, 2015 was 120.95 cents/lb. On LIFFE exchange, the price of Robusta has fallen since April 2015 to recent time. In November 2013, the prices fell to their bottoms on both exchanges after a strong increase in the middle of 2011. There were some reasons for this fluctuation.

Firstly, the expectation for a good crop affected negatively to the price of world coffee. In 2013, the information that Vietnam and Brazil harvested a successful crop in November influenced negatively the input price, leading to a sharp decrease of coffee price on two exchanges. Brazil and Vietnam respectively were the first and second biggest coffee countries exported. So the performance of crop in coffee exporting countries will influence on world coffee price. Besides, the rumors that some investors speculated coffee to influence the price of coffee also affected the coffee price.

Secondly, according to an analysis of Nguyen Quang Binh (2015), inventory in biggest coffee - consumed countries have a negative effect on the price of coffee. A report released by Green Coffee Association (GCA) showed that the amount of inventory until September 2015 in North America reached 367,027 tons. The number until July 2015 in European countries was 714,566 tons, up 19,392 tons year on year. Japan reached a recorded a number of 202.411 ton of inventory until August 2015, 7\% higher than the same period last year. As a result, the total amount of inventoried coffee in these three markets strongly influenced the price of exported coffee.

Thirdly, weather forecasts are responsible for decreasing price. For coffee industry, favorable weather forecasts create negative impact on the price of coffee. By the contrast, information of bad weather is likely to raise coffee price. In some cases, some finance institutes may whisper rumors of lean crop or bad weather adjust coffee price.

Finally, domestic currency - related information is a considerable factor to the price of coffee. Domestic currency devaluation might lead the fall in coffee price compared to other competitor countries.

\section{Fluctuation of coffee export price in Vietnam}

Price of Robusta coffee export of crop year from 2010/2011 to 2014/2015 is shown in below chart. 
(Unit: USD)

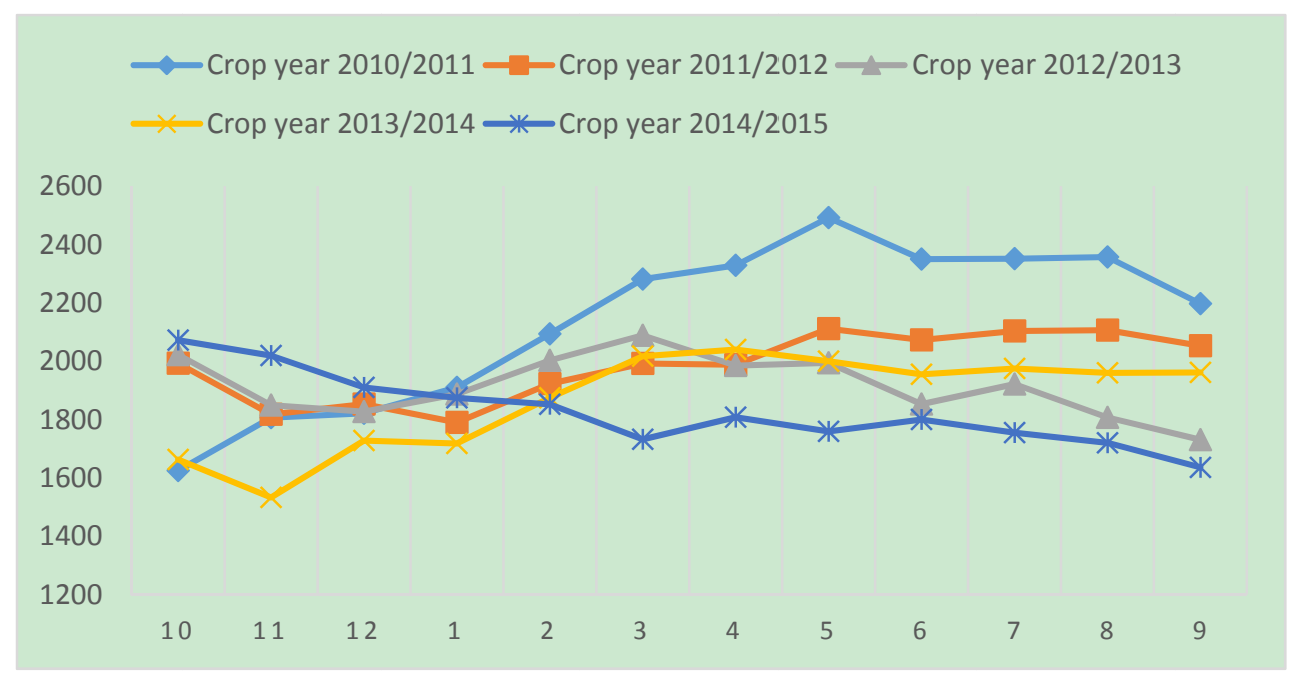

Chart 10. Price of Robusta coffee export (FOB -HCMC) crop year

Source: BCEC

As can be seen in the chart, the price of coffee in crop year 2014/2015 witnessed a gradual decrease. In addition, the prices from March to September were lowest in 5 recent years. One reason for this fall is the currency devaluation against US dollar in some competitor countries such as Brazil, Colombia and Indonesia. In some countries, level of devaluation was recorded at $50 \%$ to $70 \%$, meanwhile the number in Vietnam was $5 \%$. The changes in domestic currency in some coffee- producing countries trigger stormy selling. Although selling price was low domestic currency collection was still high and producers even earned benefit. The devaluation of Real of $70 \%$ against in Brazil led to big supply of coffee, affecting inventory of Vietnam coffee.

(Unit: USD/ton)

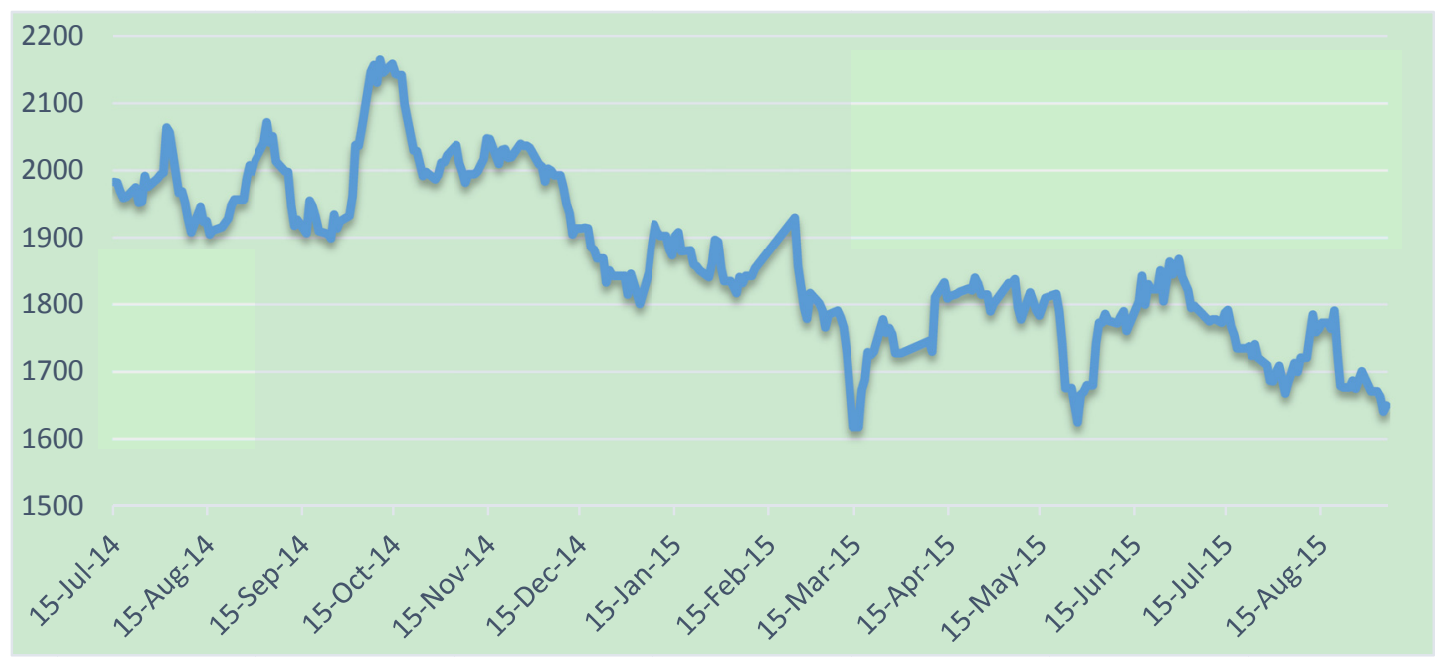

Chart 11. Fluctuation of Robusta coffee price export from Jul/2014 to Oct/2015

Source: Author summarized from BCEC

Similar to price fluctuation of world Robusta coffee, Vietnamese export Coffee price recently underwent a downward trend. In this period, coffee price drops to the lowest position by $1,571 \mathrm{USD} /$ ton in $23 / 09 / 2015$. The spot 
price of 2.5\% black burst coffee trading in Ho Chi Minh City port in 11/17/2014 is 2,047 USD/ton. This price at the date of 17.10.2015 is 1,673USD / ton. After a deep decrease period in September, coffee FOB-HCM price is likely to recover but quite light. This trend can hardly keep stable because in the next period in October and November, Highland Central households will harvest coffee, the abundance of supply will contribute to the decline of Vietnamese export coffee price.

The fluctuation of domestic Robusta coffee Price

Table 4. The fluctuation of Robusta price in crop years 2012/2013 and 2014/2015

\begin{tabular}{|c|c|c|c|}
\hline \multicolumn{4}{|c|}{ (Unit: VND/Kg) } \\
\hline & $2012 / 2013$ & $2013 / 2014$ & $2014 / 2015$ \\
\hline Oct & 41,246 & 34,636 & 40,750 \\
\hline Nov & 38,190 & 30,933 & 40,616 \\
\hline Dec & 38,057 & 34,594 & 39,718 \\
\hline Jan & 39,236 & 33,994 & 40,043 \\
\hline Feb & 40,920 & 36,495 & 39,850 \\
\hline Mar & 44,191 & 40,210 & 38,050 \\
\hline Apr & 43,005 & 40,835 & 38,741 \\
\hline May & 42,504 & 39,213 & 36,779 \\
\hline Jun & 39,078 & 38,923 & 37,739 \\
\hline Jul & 39,727 & 39,861 & 36,382 \\
\hline Aug & 39,122 & 39,467 & 36,470 \\
\hline Sep & 36,635 & 39,633 & 35,395 \\
\hline Average & 40,159 & 37,400 & 38,378 \\
\hline
\end{tabular}

Source: BCEC

As can be seen in the table the price of coffee in three recent years underwent a downward trend. The average price in crop year 2012-2013 was $40,159 \mathrm{VND} / \mathrm{Kg}$. It dropped to $37,400 \mathrm{VND} / \mathrm{Kg}$ in the following year, $6.87 \%$ lower year on year. A slight increase was recorded in crop year of 2014-2015 at 38,378 VND/Kg in which the price from March to September remained at lowest price in three recent years. The following table showed the changes of coffee price in Dak Lac from July 2014 to October 2015.

(Unit: Mil.VND/Kg)

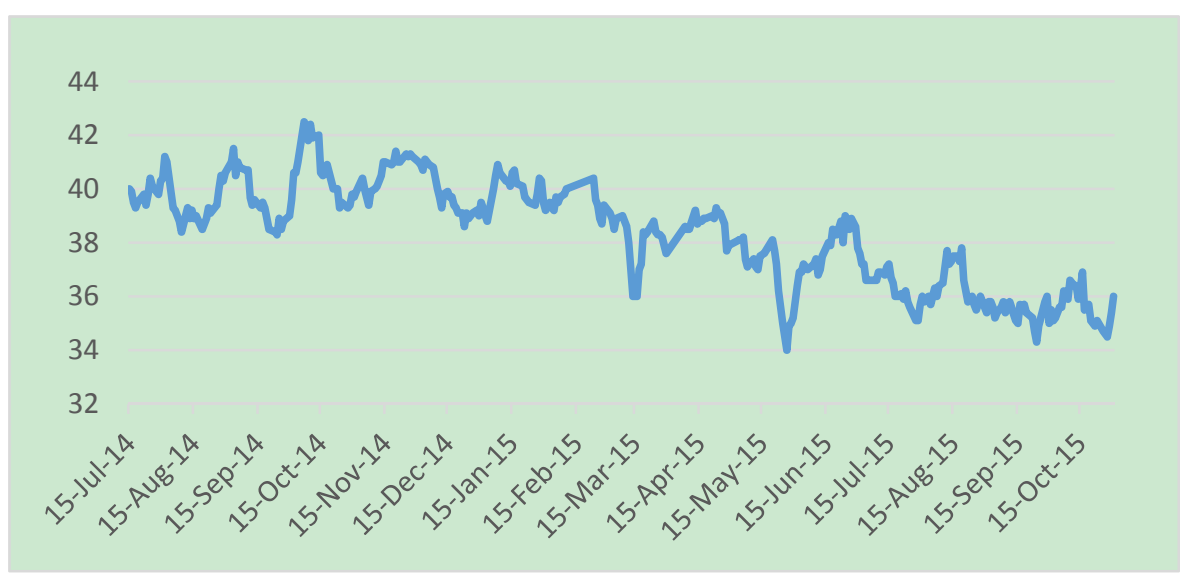

Chart 12. The fluctuation of coffee price in DakLak 2014-2015

Source: BCEC 


\section{Forecast of the fluctuation of coffee price in $2015-2016$}

There is a range of reliable organizations have given their forecast for the fluctuation of world coffee price. This paper focuses on analyzing Robusta coffee in Vietnam and other competitor countries; therefore, the price of Robusta is the center of our study.

According to a forecast of The US department of Agriculture (USDA), the total world coffee output is expected to increase by 6.4 million bags to 152.7 million bags in 2016 thanks to the impressive output in Indonesia and Honduras and the stable recovery of Brazil production, leading to the decrease in price during four years. The organization forecasted that Vietnam production would increase 28.67 million bags in which Robusta coffee accounted 27.12 million bags and Arabica coffee made up 1.05 million bags. The drying season in Highland Center in the first quarter of 2015 is not a considerable concern; the raining season starting in April creates a favorable condition for the growth of crop. It is forecasted that the coffee producing area almost remain unchanged with the moderate expansion in Lam Dong and DakLak. Robusta coffee accounts for 95\% the total production. According to the forecast of the department, the domestic purchasing power in Vietnam may be about 2.17 million bags, which means that 26.5 million bags would be exported. However, a large amount of stored coffee contributes to the long-term fall in the price of Robusta coffee in London Market. Other competitive countries producing a significant amount of coffee such as Indonesia (85\% Robusta coffee) are forecasted produce an increasing amount from 2.5 million bags to 11 million bags thanks to sound weather for blossom and fruitfulness. Export activity in Indonesia is also expected to grow from 1.4 million bags to 6.5 million bags.

According to forecasts of ICO in July 2015, crop year 2015/16 has now started in several major coffee-producing countries, including Brazil, Indonesia and Peru. The latest estimate from Conab sees production in Brazil down 2.3\% to 44.3 million bags. If realized, this volume would be the third consecutive year with lower production levels. A slight recovery is expected in Arabica production by $1.9 \%$ to reach 32.9 million bags. This rise is attributed predominantly to a significant increase of $34 \%$ in the coastal region of Zona da Mata due to better precipitation, and more modest growth in Paraná, which had been affected by low temperatures the previous year. Robusta production, on the other hand, is estimated at 11.4 million bags, $13 \%$ lower than 2014/15. This was due in large part to the recent drought in the state of Espírito Santo, the largest Robusta producing region.

Besides, basing on the released coffee price reports and world coffee price, EIU Economic and Commodity Forecast have made their forecast of world Robusta price shown in the following chart.

\section{(Unit: USD/tons)}

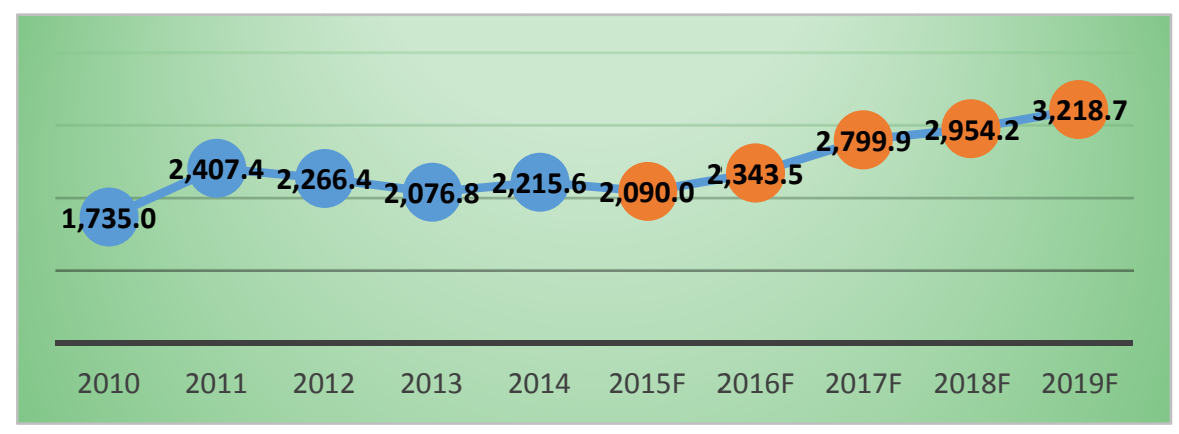

Chart 13. Coffee (Robusta) forecast in $2015-2019$

Source: EIU Economic and Commodity Forecast, July 2015

As can be seen in the chart, the price of Robusta coffee in all over the world is expected to rise in 2015-2019 period. In detail, it is forecasted that the price increase to $2,343.5 \mathrm{USD} /$ ton in 2016 , followed by a continuous soar in the coming years to reach 3,218.7 USD/ ton in 2019.

According to Vietnam Coffee and Cacao Association, the production in crop year 2014-2015 has been already harvested, $20 \%$ lower than the same period last year. In the next crop year, bad weather such as thunder during blossom period and drought during the fruitfulness period and the expansion of old tree to $30 \%$ is forecasted to affect coffee production. 


\section{Opportunities and challenges of Vietnamese export - import coffee enterprises in integration process}

At the present, Vietnam is integrating deeply and widely with a series of free trade contracts which are negotiating such as TPP, FTA with EU, Korea, America, Peru . When the ASEAN Economic Community (AEC) is officially established in 2015, Vietnam opens officially market with ASEAN countries. It can be said that until now Vietnam signed FTA with Brunei, Singapore, and Malaysia (AFTA); with Australia, New Zealand (AANZFAT) and Japan (AJCEP). These agreements commit deeper than the WTO, even some sections are not included in the WTO. It is forecasted that these agreements will bring not only opportunities but also challenges for Vietnamese enterprises in general and Vietnamese export-import coffee companies in particular.

\section{Opportunities}

Firstly, export companies will benefit from tax incentives. For the FTA poses high requirements of eliminating import taxes. For TPP demanding the abandonment of entire import duties once the agreement takes effect (except for the commodity groups of the roadmap from 3-5 years, a few have a roadmap up to 10 years). Therefore, the two countries of TPP members applying import taxes for Vietnamese coffee are Mexico (20.0\%) and Peru (11.0\%). After joining in TPP, Vietnam's coffee imported into the two markets has the opportunity to $0 \%$ tax reduction.

Besides benefiting from preferential tariffs, the coffee exporters of Vietnam also have the opportunity to expand markets. With anexpansion of markets that have a large coffee consumption like North America, EU, Japan and Russia. In addition to expanding the consuming market, the establishment of the ASEAN Economic Community will give Vietnamese companies a wider access to coffee ingredient markets such as Laos, Indonesia, and Myanmar. This will help enterprises manage risk more diversified when the domestic market is facing troubles due to crop failure, unfavorable weather.

Thirdly, with FTA agreements signed and ACE set up, Vietnam is like to attract more flow of investment and science-technology. Vietnam is encouraging foreign and domestic investors to build consuming coffee manufacturers (coffee powder, instant coffee) with modern technological equipment, diversified products of high quality assurance and food safety and meet consumer tastes. As a result of joining in TPP, agricultural protection is gradually eliminating, Vietnam will attract more foreign investors, which have modern technology to replace ineffective traditional methods.

For example, in Vietnamese harvesting coffee by hands is unlikely productive. The reason for this is that farmers are unconditional to buy machines, high-tech equipment, replanting coffee program in Highland Central to boost the productivity is still low because of lack of capital; loan interest for replanting is not really attractive for farmers and companies to invest replanting coffee trees. If there are right investments in budget and science- technology that will contribute to enhance the quality of Vietnamese coffee. Farming practices, growers' care have not improved much. Coffee structure in inappropriate places, the old coffee area increased... contribute to reducing the quality of coffee beans. When harvesting, farmers usually put fresh fruits into blender peeling in order to reduce drying time; however, coffee beans are easy to be moldy, and then firewood to make them dry but coffee beans lose their natural color. Moreover, the link among the stages of the value chain is limited.

Finally, with commitments of FAT, Vietnam has to improve political environment and policies with agriculture in general and agricultural products in particular to be transparent and stable. In Vietnam, at the moment, administrative procedures are still major problems that many businesses face. Of the nearly 7,000 comments reflected in the PCI survey of the Department of Commerce and Industry of Vietnam in 2014, there are nearly 860 opinions (12\%) saying that this is the difficulty businesses are facing. Of the 8093 respondents to the survey, as many as $23 \%$ said they have to spend more than $10 \%$ of their fund time to study and implement the laws of the State . Nearly $30 \%$ of businesses said they still have to go several times to get the seal and signature, and about $38 \%$ now disagree with the statement that the paperwork has been simplified. In addition, nearly $30 \%$ of survey respondents said they did not notice any significant change in the current administrative reform.

\section{Challenges}

Beside a range of opportunist, coffee exporting corporations may also face various challenges. The first one is the limit in implementation of risk- avoiding and risk management tools. The government, recently, has drawn and implemented some fresh and strange risk management tools. One reason is the ignorance of corporations; another is the undeveloped derivative market to manage risks. Some people, meanwhile, claim weak finance ability and lack of knowledge as a factor. This is a big challenge for Vietnamese companies to compete other producers in the global market, especially, some experienced countries who have built successful tools to avoid risk of price change. 
Moreover, when stepping in big coffee- consuming countries, Vietnamese companies usually struggle with technical food security and environmental barriers. The issue of coffee steals is increasing seriousness. In order to cope with this problem farmers have no choice but harvest their coffee which is not ripen enough, resulting in lower quality of processing and exporting coffee. More seriously, after harvesting and drying coffee farmers sell their produce to brokers who may speculate or add ropy coffee beans, reducing the quality of exporting coffee.

Thirdly, in an extreme integrated market the operation of businesses is adjusted by market. The subsidization from government is limited and government opens market for farm produce. This is an opportunity for farm produce. However, this means that the global challenges in price fluctuation, policy- related influences, technical barriers will directly affect Vietnam coffee exporters in big scale and quick pace.

The biggest drawback in the formation of an agricultural commodity future exchanges in Vietnam is characterized by the production of agricultural products in Vietnam is seasonal, based on the natural, plant area of small, fragmented so the quality is difficult to standardize to join the exchange as prescribed. Commodity exchange is lack of specific guidelines for the implementation and lack of both adequate attention of the ministries, branches and localities.

\section{Empirical Results}

\section{Price risk management tool of Vietnamese export enterprise}

\section{Domestic commodity exchange - Vietnam Commodity Exchange (VNX)}

Vietnam Commodity Exchange (VNX) is the first commodity exchange in Vietnam, which was approved to establish by Ministry of Trade and Industry in September 2010 and comply with Commercial Laws and related legal document. Since the official operation from April 1st 2011, VNX has achieved some operation results:

Table 5. Exchange operation atVNX in 2011 - 2012

\begin{tabular}{ccccc}
\hline & \multicolumn{2}{c}{ Arabica } & \multicolumn{2}{c}{ Robusta } \\
\hline Year & Volume (lot) & Value (Bil.VND) & Volume (lot) & Value (Bil.VND) \\
\hline 2011 & 21716 & 2520 & 34553 & 1627 \\
\hline 2012 & 4265 & 257.9 & 4102 & 129.2 \\
\hline Total & $\mathbf{2 5 9 8 1}$ & $\mathbf{2 7 7 7 . 9}$ & $\mathbf{3 8 6 5 5}$ & $\mathbf{1 7 6 5 . 2}$ \\
\hline
\end{tabular}

Source: Ho Thuy Ngoc and Vo Sy Manh (2013) summarize from VNX

VNX listed officially future contracts with four kind products (Note 1): Robusta, Arabia, RSS3 rubber, hot rolled steel. VNX supports exchange fees and customers are gradually familiar with trading through VNX that has attracted a large number of engagement's customers in investment. Therefore in the third quarter 2011, matched the volume of contracts of two coffee products and rubber has witnessed a significant change. Specifically, the total matched volume of Robusta coffee (VRC) reached 34553 lots, Arabica reached 21716 lots ( 1 lot $=1$ ton). The total value reaching in 2011 for coffee products equal 4147 billion VND including 2520 billion VND of Arabica coffee and 1627 mill.VND of Robusta coffee. In 2012, trading activities in VNX began having a quiet sign, especially in the second quarter 2012 when Vietnamese economy was in a difficult period, the majority of investors did not see a clear trend in operating macroeconomic Policy of the State, which made investor be reluctant and keep cash instead of pouring their money into any project. According to the report of operation result in a half of 2012 of VNX, total volume of trading contracts reached nearly 387.1 billion VND.

\section{Domestic commodity exchange - Buon Me Thuot Coffee and Commodity Exchange Center (BCEC)}

Buon Me Thuot Coffee and Commodity Exchange Center was set up in 2006 with the aim to create modern commodity distribution channels along with the traditional commodity market to build up a position for Vietnamese coffee in general and DakLak in particular. In December 2008, the Center launched immediate delivery coffee exchange which met the demand on coffee consignment to assure security, publishing and transparent exchange for participants on the market.

The establishment of Buon Me Thuot Coffee Exchange Center has helped the coffee exchange development be modernized and tune into developing economy Vietnam. In recent times, BCEC has reached some operation results: 
Table 6. Operation results at BCEC (from 01/03/2011 to 31/12/2012)

\begin{tabular}{|c|c|c|c|}
\hline & Arabica & \multicolumn{2}{|c|}{ Robusta } \\
\hline Year & Value (Bil.VND) & Volume (lot) & Value (Bil.VND) \\
\hline 2011 & \multirow{3}{*}{ No exchange } & 7739 & 686.97 \\
\hline 2012 & & 2127 & 173.14 \\
\hline Total & & 9866 & 860.11 \\
\hline
\end{tabular}

Source: BCEC

In 2011, maturing coffee exchange which was set up by BCEC's broker members has reached the positive results, with the total of matched exchange was 7739 tons, approximately 15478 tons of the total volume of exchange. The most impressive result was the result of third quarter in 2011 with the volume of matched exchange up to 2.836 lots. In 2012, BCEC's maturing coffee exchange changed total volume of matched exchanged reached 2127 lots, approximately 4254 tons.

The total value of BCEC: in the end of 2011, total value of exchanging coffee of BCEC reached 687 billion VND in which total of the third quarter of coffee products reached its peak up to 268 billion. In 2012, the value of coffee exchange products decreased significantly and reached by 173.14 billion. According to the table, the value of coffee products increased unequally in each quarter that shows coffee exchange activities at BCEC has had fluctuation recently.

The structure of members who take part in trading activities through BCEC: until 2012, the center has developed with 90 members in which there are 63 selling members, 23 business members, and 4 broker members.

From the results of VNX and BCEC shows that the use of derivative products and activities of enterprises is quite limited. The total volume of exchange is not over $1 \%$ total volume of coffee in whole country and makes up a small percent of coffee exported output. There are many reasons triggering companies engage in this market.

\section{Use of derivative tool in foreign commodity exchange}

In recent years, complicated changes in the economy and global climate change make the world agricultural products decline seriously, the price of products has complicated changes. These factors have big impacts on manufacturing and exporting activities of domestic enterprises. The main Vietnamese agricultural products such as: rice, coffee, pepper with large volume has engaged in adjusting the world price. However, the majority of Vietnamese selling price is all lower than regional countries. This is due to producing process, traditional consuming goods and unequal goods' quality. At the same time, standard of Vietnamese commodity is often not recognized in the world, which leads a big lose for enterprises, especially farmers. Moreover, because of the lack of exchanging good tool, producers and trader have to face troubles. Almost Vietnamese export enterprises do not have provision tools and fluctuation price insurance. For producers, their finance mainly depends on the bank's credit and government incentives, whichare still limited. At present, nearly $99 \%$ enterprises exchange activities are done by the traditional methods that is buying first and then delivering and receiving.

In this case, not few companies engage in maturing exchange at foreign exchange such as exchanging Robusta coffee at LIFFE in London, Arabia coffee at NYBOT in America, TOCOM in Japan. From the end of 2004, companies have taken part in trading in international markets, especially maturing Robusta exchange at LIFFE in London. With this kind of exchange, enterprise only needs to sign a small of amount of money approximating to some percents in comparison to the value of exchange good which is able to sell and buy directly without having storage goods, save the cost of loan interest, storage and delivery much. Understanding the demand of enterprises, some Vietnamese banks started taking part in brokering such as Techcombank. After Techcombank, until July 2006, BIDV was approved for pilot derivative good specialization by the State bank. Techcombank and BIDV are evaluated as one of the prestige and experienced banks in this field. After the approval of these two banks, other banks also are approved by the State bank to launch derivative commodity specialization like VCB, MB, Sacombank, PGBank, Vietinbank.

\section{Applications for development of derivatives in Vietnam}

This part mainly focuses on introduction of experience lessons of success cases which is revealed in previous researches. From seven country case studies of Euna Shim (2006), it is found that the most important success factors of the agricultural futures market in developing countries which is shown in below table: 
Table 7. Success factors of agricultural commodity futures market

\begin{tabular}{ll}
\hline \multicolumn{1}{c}{ Factor } & \multicolumn{1}{c}{ Exchange (Country) } \\
\hline Macroeconomic stability & $(1),(2),(3),(4),(5),(6),(7)$ \\
\hline Contract that is substantially different from existing ones & $(1),(3),(4)$ \\
\hline Presence of large domestic physical markets & $(1),(2),(3),(4),(5),(6),(7)$ \\
\hline Well - establish financial intermediaries & $(1),(3),(4)$ \\
\hline Role of regulation and clearing house & $(1),(2)$, \\
\hline Contract with a large basis risk & $(4)$ \\
\hline Industry integration level & $(3),(5),(6),(7)$ \\
\hline Export orientation & $(3),(4)$ \\
\hline Committed actors & $(4),(5)$ \\
\hline Note: & \\
(1) National Commodity \& Derivative Exchange Limited (NCDEX), India & \\
(2) South African Futures Exchange (SAFEX), South Africa & \\
(3) Bursa Malaysia Derivatives (MDEX), Malaysia & \\
(4) The Jakarta Futures Exchange (JEX), Indonesia & \\
(5) Brazillian Mercantile and Futures Exchange (BM\&F), Brazil & \\
(6) Mercado a Término de Buenos Aires S.A. (MATBA), Argentina & \\
(7) Agricultural Futures Exchange of Thailand (AFET), Thailand & \\
\hline
\end{tabular}

Source: Euna Shim (2006)

According to findings of Euna Shim (2006), it is revealed briefly that the most of success factors of agricultural commodity futures exchange in developing countries, including four sectors: large domestic physical market, government regulation, macroeconomic performance and well - establish financial intermediaries. Besides, by researching the commodity derivatives market in Vietnam, Nguyen Phuoc Kinh Kha (2014) also argued that condition of commodity derivatives development is underlying products, government regulation, financial institutions and technology conditions. This is similar to the findings of Pham Nguyen Hoang (2011) about forming conditions and market development in Vietnam. According to this, condition to develop future contract market includes: mechanism-law, economy-finance- technology.

In the limitation of this study, due to the lack of knowledge and reality, criteria suggesting for developing the derivative market will be summarized in the previous studies (Euna Shim, 2006; Nguyen Phuoc Kinh Kha, 2014; Pham Nguyen Hoang, 2011, Le Hoang Nga, 2011). Therefore, conditions to develop derivative market will be analyzed in 4 factors: underlying products, economy- finance- financial market, regulation and technical condition.

In terms of underlying products, this is the foremost condition to develop derivative product exchange and enhance strongly functions, outstanding advantage of exchange in the economy. The more diverse Underlying products are, the better quality of products is, and products are produced massively and stably, if the product's information is full and transparent, derivative product exchange develops strongly (Euna Shim, 2006). On the other hand, policies maintain stability and development of underlying products plays also an important role in order to provide enough products for the development of derivative exchange market (Nguyen Phuoc Kinh Kha, 2015).

In term of legislative condition, according to Pham Nguyen Hoang (2011), market economy is the foremost condition for establishing exchange demand of other derivative products and derivative market is a character of planned economy. Legislative producers with an aim to establish and develop derivative market is a legislative barrier to ensure establishing condition, take part in derivative exchange activities. On the other hand, the Legislative document system will encourage and support exchanges on improving, developing new products. Do Thi Kim Hao (2012) concluded that the establishment of accounting criteria about derivative specialization which is suitable with international practice, set up daily mark to market system of margins. Shim (2006) stressed to categorize among managing function, market supervision and derivative exchange on market. Because the character of derivative market is able to exchange different kind of products, it relates to managing limitation of specialized managing organization and leads to beneficial conflict easily. If there is overlap and ambiguity on function, managing assignment, market supervision, it will be easy to be a failure of derivative market (Nguyen PhuocKinhKha, 2015).

In term of economic and financial condition, this index is reflected through macro and micro data of the economy, which shows the reality of commercial banks and developed economy policies. Macro and Micro statistic reflects the wealth of a stable economy and the willing to new exchanges which are more developed and modern than 
exchanging derivative products. International economic integration will reflect the favorable conditions to stimulate exchanging derivative product because these exchanges not only meet domestic purchasing needs but also are connected with international market and exchange stocks. The power of the commercial bank system will insure for engagement, support, and connection for bank products with goods derivation exchange (Nguyen PhuocKinhKha, 2015; Euna Shim, 2006).

In term of technology, in order to operate derivatives, terms in contracts are needed to be standardized under international treaty such as regulation in types of asset used as underlying products for derivative contract, conditions to publish exchange, the amount of each exchanged (Do Thi Kim Hao, 2012). Standard terms in contracts must include quantity, unit of product, minimum price amplifier, exchange time, payment time, and date of last exchange. Besides, for some special products, there are some added regulations such as delivery term, delivery procedure, and maximum price amplifier. Moreover, for the sake of the development of derivative, modern infrastructure investment is vital, especially, the development ò technology to deal with payment process and connection to global exchange (Von Braun et al., 2005; Pham Nguyen Hoang, 2011).

\section{Quantity tool use for hedging price risk for Vietnam coffee export}

In order to recognize the level of price risk the standard deflection method is used as a striking sample. This is a simple accounting. The fluctuation of export coffee price is determined by determining the average price, the highest price, the lowest price, variance and standard deflection in which variance is the total of square of defections between the price at a period $t$ and the average price during a period. Variance is accounted by this formula:

$$
\sigma^{2}=\sum \frac{\left(p_{t}-p_{\mu}\right)^{2}}{n}
$$

Where:

$$
\begin{aligned}
& \sigma^{2} \text { is variance } \\
& p_{t} \text { is coffee price at time t } \\
& p_{\mu} \text { is average of coffee price } \\
& \text { Nis observations }
\end{aligned}
$$

Meanwhile, the standard deviation $(\sigma)$ is the square root of the variance prices. In this study, the authors conducted research on the standard deviation is pricing period by month and by year with expectations that the standard deviation is calculated over a period as short as it would result reflects more precision.

It is well seen from the below chart 14 of standard deviation of coffee price on LIFFE exchange, the price of Robusta fluctuated slightly in April, May and November because November usually is harvest time in coffee producing countries. However, the price usually swings in the end and middle of crop year. The standard deviation of coffee price on LIFFE exchange is calculated based on Model 1.

\section{(Unit: USD/ton)}

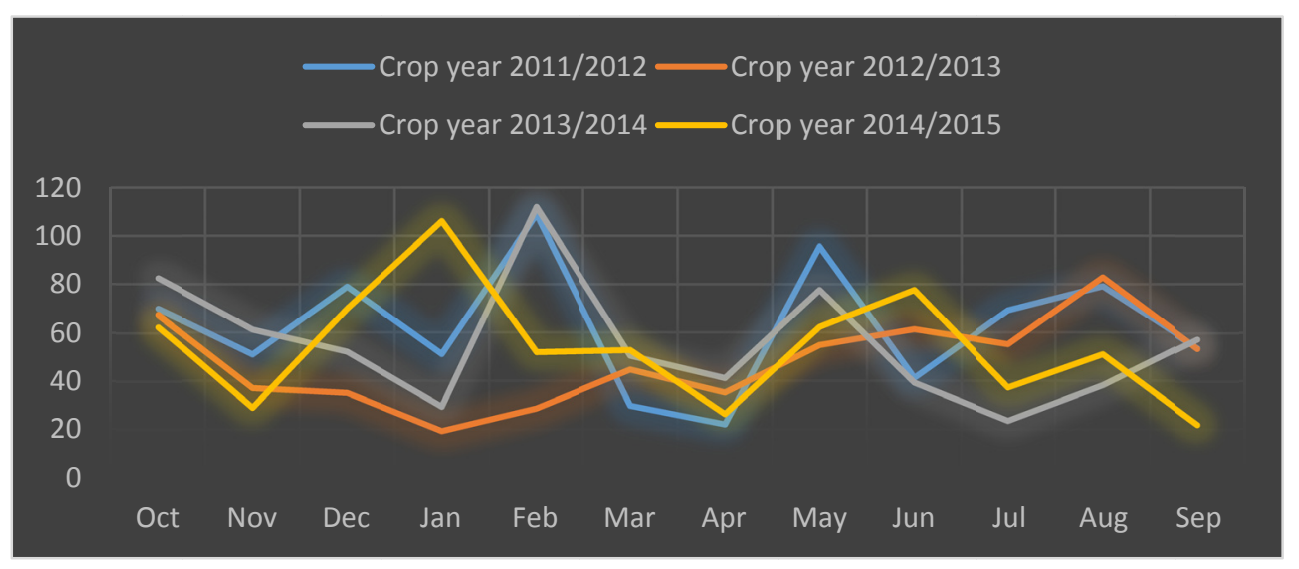

Chart 14. Standard deviation of Robusta coffee price in LIFFE 2011 - 2015 
The following table illustrates the standard deviation of coffee price in 2014-2015 crop year, including Robusta price on LIFFE exchange and coffee export price and domestic price. Standard deviation is calculated based on Model 1.

Table 8. Standard deviation of Robusta coffee price in crop year 2014/2015

\begin{tabular}{cccc}
\hline Period & $\begin{array}{c}\text { Robusta coffee price on } \\
\text { LIFFE } \\
\text { (USD/ton) }\end{array}$ & $\begin{array}{c}\text { FOB Price } \\
\text { (USD/ton) }\end{array}$ & $\begin{array}{c}\text { Domestic Robusta coffee } \\
\text { price } \\
\text { (Mil. Dong/ton) }\end{array}$ \\
\hline Aug/2014 & 38.212202 & 46.325556 & 0.8051915 \\
\hline Sep/2014 & 57.389280 & 55.071382 & 0.9986658 \\
\hline Oct/2014 & 62.534381 & 70.062141 & 1.0582819 \\
\hline Nov/2014 & 28.939743 & 19.024921 & 0.6152042 \\
\hline Dec/2014 & 69.802610 & 63.831858 & 0.7795857 \\
\hline Jan/2015 & 106.153324 & 29.668478 & 0.5431191 \\
\hline Feb/2015 & 51.793517 & 34.528536 & 0.4287088 \\
\hline Mar/2015 & 52.695831 & 52.541635 & 0.9044503 \\
\hline Apr/2015 & 26.325164 & 28.78176 & 0.4228753 \\
\hline May/2015 & 62.231939 & 69.718146 & 1.3104617 \\
\hline Jun/2015 & 77.616732 & 43.938198 & 0.7715033 \\
\hline Jul/2015 & 37.254174 & 40.726893 & 0.6879827 \\
\hline Aug/2015 & 50.995984 & 40.455289 & 0.7549714 \\
\hline Sep/2015 & 21.958096 & 25.860797 & 0.4143923 \\
\hline Oct/2015 & 38.21220 & 35.84224 & 0.6525689 \\
\hline
\end{tabular}

The above table shows the standard deviation of Robusta price on LYFFFE exchange, coffee exporting price in Vietnam and domestic price. As can be seen on the table, the price of coffee in the recent year witnessed a strong and irregular fluctuation in September, October, December; especially, May 2015. In October, 2014 the standard deviation of Robusta price on LIFFE was $62.53 \mathrm{USD} /$ ton, meanwhile the FOB price fluctuation in Vietnam was $70.06 \mathrm{USD} / \mathrm{ton}$, and the fluctuation of domestic price was $1.058 \mathrm{bill} \mathrm{dong} / \mathrm{ton}$. Global and domestic coffee price in September and October, 2015; however, underwent stability. The reason of changes in September and October, 2014 are the start of the new crop year, the significant amount of inventory, wait of price rise from growers, at the same time, the high demand of corporations to conduct contract. Therefore, the disparity between sellers and buyers was the main factor of price fluctuation. In addition, when a crop year stopped and a new year came, investors speculate to rumor that the El Nino effect negatively influenced the coffee production of growing countries such as the second country Vietnam. It is recognized from statistics on LIFFE exchange, contracts in September and October 2014 saw improvement, leading to strong fluctuation. In October2014, Robusta price reached its peak in recent year.

In March 2015, prices fell because it was the end of Lunar year in Vietnam, corporations wanted to complete contracts to summate business performance and grant incentive salary for employee. The export urge of many companies resulted in price plunge. Significantly, the price on 14/03/2015 fell into its bottom during a period of 15 months.

The plunge in the end of crop year 2014-2015 was not decided by supply- demand law but mainly speculation of investors. Another reason was the disadvantage of devaluation of domestic currency of some producing countries such as $40 \%$ devaluation of Real against USD. The devaluation provided a favorable condition to coffee export sector in these countries. In ASIA, the completion of Vietnam coffee and Indonesia coffee also led to the $20 \%$ devaluation of Rupia.

Econometric regression for price forecast

According to Bold Sandagdorj (2005), copper price prediction is applied that based on below mathematical model (1):

$$
\left\{\begin{array}{c}
\ln \left(Q_{t}^{D}\right)=\propto_{1}+\propto_{2} \ln \left(P_{t}\right)+\propto_{3} \ln \left(G D P_{t}\right)+\propto_{4} I P_{t}+\varepsilon_{t} \\
\ln \left(Q_{t}^{S}\right)=\beta_{1}+\beta_{2} \ln \left(P_{t}\right)+\beta_{3} \ln (T)+\beta_{4} \ln \left(P_{O I L}\right)+\beta_{4} \ln \left(U S D I_{t}\right)+\beta_{5} \ln \left(L I B O R_{t}\right)+\mu_{t} \\
Q_{t}^{D}=Q_{t}^{S}
\end{array}\right.
$$


Where:

$Q_{t}^{D}$ : Quantity of copper demand at time $\mathrm{t}$

$Q_{t}^{S}$ : Quantity of copper supply at time t

$P_{t}$ : Monthly LME copper price at time $\mathrm{t}$

$T$ : Time

$G D P_{t}$ : Monthly world GDP at time $\mathrm{t}$

$U S D I_{t}$ : US Dollar Index at time $\mathrm{t}$

$I P_{t}:$ Global industrial growth at time $\mathrm{t}$

$P_{\text {OIL }}$ : crude oil price at time $\mathrm{t}$

$\operatorname{LIBOR}_{t}: 6$ - month London Interbank Offered Rate at time t

From model (1), the endogenous variable that appears as an explanatory variable is the lagged price of copper. Therefore, the dependent variable is the lagged price of copper $\mathrm{P}$ and all predetermined variables are GDP, IP, T, $\mathrm{P}_{\mathrm{OIL}}$, USDI and LIBOR in the reduced form equation. The transferred function of model has form:

$$
\operatorname{Ln}\left(P_{t}^{R C}\right)=\delta_{1}+\delta_{2} \operatorname{Ln}\left(G D P_{t}\right)+\delta_{3} I P_{t}+\delta_{4} \operatorname{Ln}(T)+\delta_{5} \ln \left(P_{\text {OIL }}\right)+\delta_{6} \ln \left(U S D I_{t}\right)+\delta_{7} \ln \left(\text { LIBOR }_{t}\right)+\mu_{t}
$$

Besides, in term of this paper, authors introduced model to forecast LIFFE Robusta coffee price as a function:

$$
\operatorname{Ln}\left(P_{t}^{R C}\right)=\beta_{0}+\beta_{1} \operatorname{Ln}\left(U S D I_{t}\right)+\beta_{2} \operatorname{Ln}\left(\operatorname{LIBOR}_{t}\right)
$$

The reason of reject two variable as $P_{O I L}$ andGDPis because of significant correlation between $P_{O I L}$ and USDI variable and limitation of collecting monthly world GDP. Therefore, we introduce two explanatory variables including USDI (US Dollar Index) and LIBOR (6 - month London Interbank Offered Rate). Monthly data of USDI is set out from 2005 to 2015 by http://www.investing.com/quotes/us-dollar-index. Besides, LIBOR data is conducted by Federal Reserve Economic Data. Robusta coffee price is author summarize in LIFFE.

Table 9. Econometrical regression for Robusta coffee prediction

Dependent Variable: LOG(ROBUSTA COFFEE PRICE)

Method: Least Squares

Sample: 1130

Included observations: 130

\begin{tabular}{lcccr}
\hline \hline \multicolumn{1}{c}{ Variable } & Coefficient & \multicolumn{1}{c}{ Std. Error } & t-Statistic & Prob. \\
\hline \hline \multicolumn{1}{c}{ LOG(USDI) } & -1.574261 & 0.271655 & -5.795073 & 0.0000 \\
\multicolumn{1}{c}{ LOG(LIBOR) } & -0.096691 & 0.017692 & -5.465391 & 0.0000 \\
\multicolumn{1}{c}{ C } & 14.38490 & 1.198464 & 12.00278 & 0.0000 \\
\hline \hline R-squared & 0.339955 & Mean dependent var & & 7.428054 \\
Adjusted R-squared & 0.329560 & S.D. dependent var & & 0.263548 \\
S.E. of regression & 0.215794 & Akaike info criterion & & -0.206175 \\
Sum squared resid & 5.914033 & Schwarz criterion & & -0.140002 \\
Log likelihood & 16.40141 & Hannan-Quinn criter. & & -0.179287 \\
F-statistic & 32.70554 & Durbin-Watson stat & & 0.244918 \\
Prob(F-statistic) & 0.000000 & & \\
\hline \hline
\end{tabular}


From regression results, the significant statistical of USDI and LIBOR variable implied that they have a negative impact on Robusta coffee price. If other factors remain unchanged, when USDI and LIBOR increased 1 units leading to Robusta coffee price would decrease-1.574261, -0.096691 units, respectively.

Finally, function prediction of Robusta coffee is conducted as:

$$
\operatorname{Ln}\left(P_{t}^{R C}\right)=14.4849-1.574261 \operatorname{Ln}\left(U S D I_{t}\right)-0.096691 \operatorname{Ln}\left(\operatorname{LIBOR}_{t}\right)
$$

This above function can betransferred to:

\section{Conclusion}

$$
P^{R C}=e^{14.4849} \cdot U S D I^{-1.574261} \cdot \text { LIBOR }^{-0.096691}
$$

The commodity derivatives are studied to hedge price fluctuation risk of coffee exporting corporations in Vietnam. The research shows the following findings.

Derivatives in Vietnam are in their development process, the development of commodity exchanges in Vietnam is still disadvantageous. In 2012-2015 periods, a range of commodity exchanges was set up. However, the performance of those exchanges was not effective, and after a short time of operation, they closed down. The lack of connections among investors on those exchanges and lack of legislative mechanism and regulation led to ineffectiveness (Nguyen Phuoc Kinh Kha, 2015; Ho Thuy Ngoc and Vo Sy Manh, 2013). The operation of exchanges, coffee in particular was limited and mainly conducted by commercial banks, broker.

The coffee export sector has reached some significant achievements and is expected to develop. Although last years of 20th century Vietnam coffee production was low, in 2015 Vietnam is the second biggest coffee exporter and the biggest Robusta exporter. With significant development, coffee sector plays a crucial role in the growth of Vietnam agriculture and Vietnam economy.

The establishment of tools to hedge price fluctuation of exporters in Vietnam is limitable. The results are well seen the total amount of coffee exchanged in Vietnam and the valuations of experts. According to Theo Ho Thuy Ngoc and Vo Sy Manh (2013), above 99\% of Vietnamese coffee export companies do not have derivative tools to avoid risk in price change. A research of Nguyen Phuoc Kinh Kha (2015) which examined 250 coffee growing households in Lam Dong revealed that $80 \%$ of them were unaware of benefits of derivative tools, $92 \%$ were not introduced and trained about derivative tools, $84 \%$ sold their produce through indirect channel.

Finally, the development of derivative commodity exchange and usage of derivatives tools to avoid risk in price fluctuation of Vietnam corporations require the accomplishment of legislative foundation, completion of payment method, the diversity of exchange method, the improvement of infrastructure, enhancement of management role, the accomplishment of accounting system and financial system, the transparence of commodity information, the completion of goods exchange conditions, the completion of commodity exchange (Nguyen Phuoc Kinh Kha, 2015).

\section{References}

Antonaci, L., Demeke, M., \& Vezzani, A. (2014). The challenges of managing agricultural price and production risks in sub-Saharan Africa, ESA Working paper No. 14 - 09.

Firdu Gemech, Sushil Mohan, Alan Reeves \& John Strthers. (2009). Market-Based Price-Risk Management: Welfare Gains for Coffee Producers from Efficient Allocation of Resources.

Ojasalo, J. (2009). A Model of Risk Management in Globalizing Companies. The Business Review, 13.

Patrick de Fontenay, \& Suiwah Leung. (2002). Managing commodity price fluctuations in Vietnam's coffee Industry. International and development economic Working paper No. $02-04$.

Randall Dodd, \& Stephany Griffith - Jones. (2007). Brazil's Derivatives Markets: hedging, central bank intervention and regulation.

Shim, E. (2006). Success factors of agricultural futures markets in developing countries and their implication on existing and new local exchanges in developing countries. The Fletcher School, Tufts University, 26 April.

UNCTAD. (2011). Unraveling the underlying causes of price volatility in world coffee and cocoa commodity market.

Von Braun, J., Gulati, A., Hazell, P., Rosegrant, M. W., \& Ruel, M. (2005). Indian agriculture and rural development: Strategic issues and reform options. IFPRI Strategy Paper. Retrieved from http://www.ifpri.org/pubs/ib/ib35.pdf

\section{Note}

Note 1. Robusta coffee future contract and Arabica coffee future contract are inserted in Appendix 1 (1A and 1B, respective) 